\title{
The Acquisition of English Speaking Skills of Small Traders in Hanoi's Old Quarter
}

\author{
Vu Hai Ha*, Nguyen Tran Tram Anh \\ VNU University of Languages and International Studies, Pham Van Dong, Cau Giay, Hanoi, Vietnam
}

Received 02 August 2016

Revised 26 September 2016; Accepted 22 December 2016

\begin{abstract}
The recent increase in the number of foreign visitors to Vietnam highlights the necessity for the improvement of English speaking skills of small traders in Hanoi’s Old Quarter - a popular tourist destination in Vietnam, where English is pivotal in both trading and promoting Vietnamese culture. In that context, this research explores how these traders could acquire their English speaking skills in their own living contexts. Adopting both qualitative and quantitative methods, particularly observation, interviews with small traders $(n=23)$ and survey questionnaires combined with interviews with foreigners $(\mathrm{n}=100)$, the research has reached two major conclusions. First, unlike popular assumptions that small traders learn English through contact with foreigners, the sources of their English acquisition were much more diverse. Secondly, small traders were expected to speak English well not only to carry out transactions but also to aid foreigners in a wide range of functions, ranging from navigating through the streets to better understanding Vietnamese culture. However, the English speaking skills of these traders were often found insufficient in terms of grammatical, discourse, and sociolinguistic competences. From the collected data, the article suggests a number of different ways to enhance the small trader's acquisition of English speaking skills.
\end{abstract}

Keywords: Small traders, Hanoi's Old Quarter, English language acquisition, international tourism.

\section{Introduction}

According to Vietnam National Administration of Tourism [1], Vietnam witnessed a $24 \%$ growth in the number of international visitors within the first seven months in 2016. This upward trend underscores the need to enhance the English speaking skills of small traders in Hanoi's Old Quarter, one of the most popular tourist attractions in Vietnam. As English has been widely considered an international language, decent English speaking skills would undeniably aid small traders in

\footnotetext{
* Corresponding author. Tel.: 84-983536788

Email: havh@vnu.edu.vn
}

their business and transactions, as clearly put by one trader [2]: "Không nói được tiếng Anh hả? Vậy buôn bán khó lắm em ơi!" (Cannot speak English? Then it would be hard to do business!). Additionally, good English speaking competence also allow small traders to introduce Vietnamese cultural images and values among foreigners, thus promoting Vietnam's image during their transactions.

Despite the significant importance of English speaking skills for small traders, few studies have been made to figure out what should be done to support their acquisition of these skills. The traders are often left unaided in their English language learning, whose efforts often ended up with unsatisfying outcomes $[3,4]$. 
As an attempt to address this issue, this research examines the current English speaking acquisition strategies from the perspectives of both the traders and the foreigners in their daily transactions. It specifically aims at answering two main research questions below:

1. From which sources do small traders in Hanoi's Old Quarter acquire their English speaking skills?

2. How competent is their English speaking, as assessed by the foreign customers?

By answering these two questions, educational implications for their English language acquisition could be put forward. Moreover, even though the participants in this research were small traders in Hanoi's Old Quarter, similar implications could be suggested to small traders in other areas in Vietnam as well.

\section{Overview of the literature}

\subsection{Speaking, and English speaking skill acquisition}

Brown (1994) and Burns \& Joyce (1997) [as cited in [5] define speaking as an interactive process of meaning construction that involves producing, receiving and processing information. The process, as asserted by Bygate [6], requires not only prompt decision making and fluent delivery, but also appropriate adjustments when problems arise. All of these factors are shaped by the context, the participants, the speakers' experiences, the environment and the speaking purposes (Florez, 1999, as cited in [7]).

As for English speaking skill acquisition, it is a process whose outcome depends on a wide variety of factors, including the sources of the target language and the learners' strategies in handling those sources. Regarding the former, Ellis [8] articulates that the learning process may take place in a "natural" environment through conversations with native speakers, or in a "tutored setting" under guidance of teachers and the aid of learning "facilities" such as textbooks, videos, the Internet, etc. [9]. In either case, language acquisition happens when the input language is of a higher level than that of the language learners as learners could learn meaning before acquiring the structures of the language [10]. Sometimes, in order for the acquisition to take place, the input language is often modified to fit the language level of the learners [8].

From these learning sources, different learners employ different strategies to absorb the new language, which is articulated by Tarone (1980, cited in [8]) as "the means by which the learner processes the L2 input in order to develop linguistic knowledge" (p.13). They may learn through memorization" and repetition; production strategies (i.e., inferencing, overgeneralization, and rehearsing); or communication strategies (e.g. requests for assistance and paraphrase).

\subsection{Assessing English speaking competence}

Since the communicative approach has been popular in the field of teaching and learning English speaking skills, as postulated by Littlewood [11] and Richards [12], an English learner's proficiency in speaking can be measured by his or her communicative competence. This paper employs the English competence assessing model put forward by Canale (1983) [as cited in [13]] illustrated in Figure 1.

To the best of our knowledge, there have been numerous studies on the English speaking skill acquisition among Vietnamese learners, yet few have been done on that of small traders in Hanoi's Old Quarter. Given the considerable impacts their English speaking has on both the individuals and the society, we decided to enquire into the acquisition of their English speaking skills through a study outlined below.

\section{Research methods and procedure}

In this study, a combination of both quantitative and qualitative methods is 
employed. The data collection process took place from January to August 2016. The whole process can be divided into three phrases as followed:

First, the researchers observed the conversations between small traders in Hanoi's
Old Quarter and foreign visitors. After that, 23 small traders were chosen via convenient sampling for semi-structured interviews (Table 1). The main objective was to find out how these traders acquired their English speaking skills (Table 1).

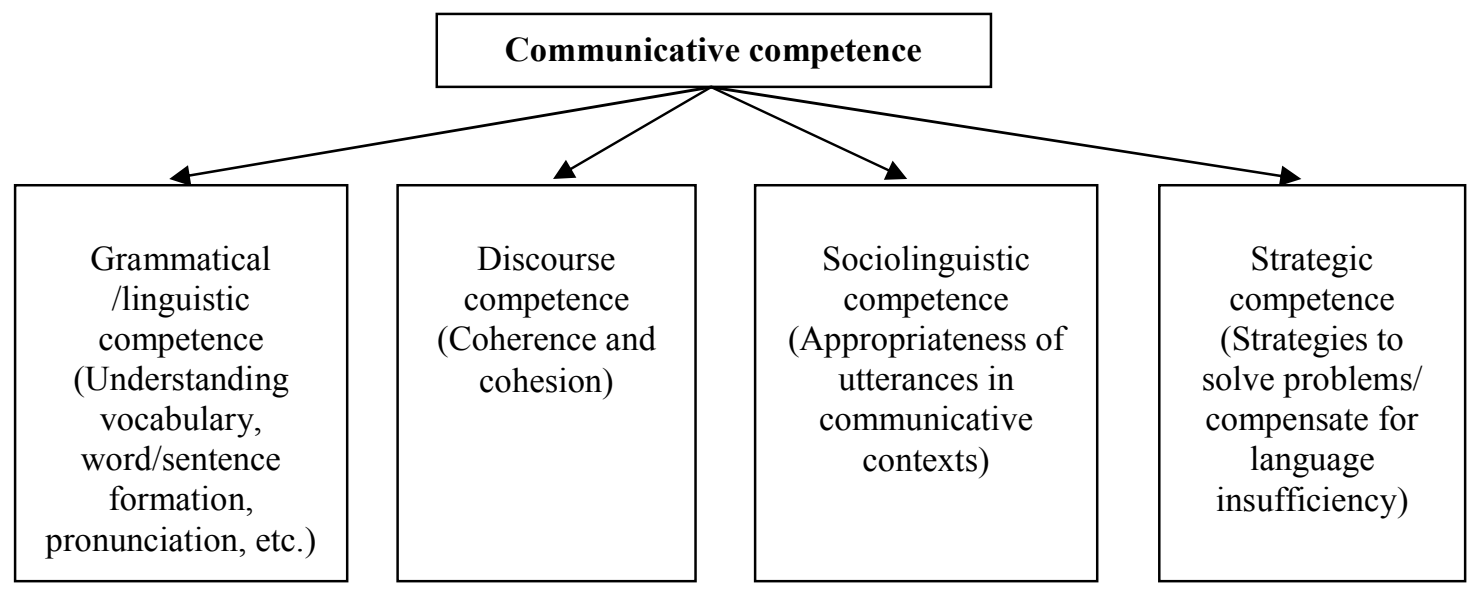

Figure 1. Communicative competence model by Canale [cited in 13].

Table 1. The research participants: The small traders

\begin{tabular}{cccccc}
\hline No & Name & Age/gender & $\begin{array}{c}\text { Type of } \\
\text { merchandise }\end{array}$ & Location & $\begin{array}{c}\text { Business experience at } \\
\text { Hanoi's Old Quarter }\end{array}$ \\
\hline 1 & Hoa & $30-$ female & shoes & Hang Dau & A month \\
2 & Phuong & $50-$ female & shoes & Hang Dau & 10 years \\
3 & Lien & $30-$ female & shoes & Hang Dau & 3 months \\
4 & Hanh & $26-$ female & clothes & Hang Dau & A month \\
5 & Hung & $70-$ male & souvenirs & Dinh Tien Hoang & 15 years \\
6 & Mai & $35-$ female & bags & Dinh Tien Hoang & Few months \\
7 & Luong & $40-$ male & souvenirs & Đinh Liệt & 10 years \\
8 & Ly & $40-$ female & Seed, food & 13 Hang Buom & 10 years \\
9 & Ngoc & $40-$ female & bags & Dinh Tien Hoang & 20 years \\
10 & Nhu & $40-$ female & clothes & Hang Ngang & Long time \\
11 & Huyen & $40-$ female & bags & Ngo Huyen & Few years \\
12 & Huong & $22-$ female & souvenirs & Ly Quoc Su & Few months \\
13 & Ha & $40-$ female & paintings & Ly Quoc Su & 10 years \\
14 & Yen & $30-$ female & propaganda & Ly Quoc Su & 3 years \\
15 & Nguyet & $35-$ female & propaganda & Ly Quoc Su & Few monts \\
16 & Nhan & $60-$ female & souvenirs & Ly Quoc Su & Decade \\
17 & Dung & $36-$ female & souvenirs & Ly Quoc Su & 3 months \\
18 & Lan & $40-$ female & antiques & Tan Viet & 20 years \\
19 & Hien & $35-$ female & souvenirs & Nha Tho & 10 years \\
20 & Chi & $59-$ female & clothes & Dinh Liet & 44 years \\
21 & Kieu & $29-$ female & clothes & Dinh Liet & 5 years \\
22 & Trang & $29-$ female & souvenirs & Hang Dao & 1 year \\
23 & Minh & $23-$ female & leather items & Hang Dao & 7 years \\
\hline & & & &
\end{tabular}


In the second stage, the researcher distributed questionnaires to 100 foreign visitors (Table 2) who had conversations with small traders in Hanoi's Old Quarter to gather their assessment on the English speaking skills of these small traders. After collecting data from the questionnaire, the researcher invited 19 foreigners who directly had conversations with the small traders listed in Table 1 to have semi-structured interviews. Whereas not all of the foreign participants spoke English as a mother tongue or an official language, it could be argued that as long as English is taken as an international language, speakers of English as a foreign language are also qualified enough to assess the intelligibility and effectiveness of their conversations in English.

Table 2. The research participants: The foreign customers

\begin{tabular}{lcc}
\hline $\begin{array}{l}\text { Nationality of } \\
\text { foreign customers }\end{array}$ & Number & Sum \\
\hline English is the native/official language & \\
Australian & 20 & \\
American & 10 & \\
British & 12 & \\
Canadian & 12 & 64 \\
New Zealander & 6 & \\
Singaporean & 1 & \\
Irish & 1 & \\
South African & 2 & \\
English is a foreign language & \\
German & 11 & \\
Dutch & 2 & \\
French & 8 & \\
Argentinian & 4 & \\
Russian & 2 & \\
Italian & 2 & 36 \\
Spanish & 1 & \\
Czech & 1 & \\
Uruguayan & 2 & \\
Hungarian & 2 & \\
Japanese & 1 & \\
TOTAL & & 100 \\
\hline
\end{tabular}

\section{Results and discussion}

\subsection{English speaking skill acquisition of small traders in Hanoi's old quarter}

Vietnamese media usually attribute the English speaking skill acquisition of small traders to interaction with foreigners $[15,16]$. However, from the collected data, this paper contends that the English speaking skills of small traders in Hanoi's Old Quarter stem from various sources.

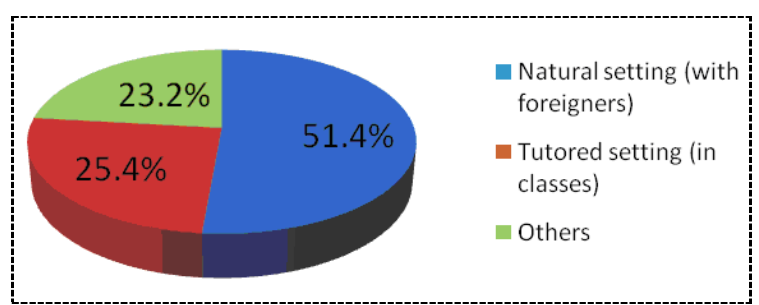

As can be seen in the pie chart, more than half of the interviewed small traders mainly acquired their English speaking skills from foreign tourists. Ms. Hien, a 35-year old owner of a souvenir shop, said that daily contact with foreign customers allowed her to have better fluency and confidence in communication: "At first when I used English, I felt ashamed. It was hard to utter the words; but now that I communicate on a regular basis, I feel normal".

Tutored settings ranked second in terms of popularity with $25.4 \%$ of small traders. Most traders in this groups said that they learned most of their English at high school, but more often than not, it was grammatical knowledge and proved unhelpful in their daily communication. Hanh, a 26 year-old female trader selling clothes, admitted:

I studied English at school. I do not have any extra classes. So when I started selling here I could not speak much. But the longer I sell, the more I communicate with foreign customers, the more I learn, much more than I did at school.

Besides, some opted for online learning or attended classes at English centers. But all of them agreed that communicating with foreigners was the fastest way to acquire speaking skills.

Apart from those afore-mentioned factors, small traders also relied on other sources for the improvement of English speaking skills, 
including learning from their relatives (13.2\%), or indepdent learning via dictionaries $(4.3 \%)$ and books (5.7\%).

Regarding learning strategies, the most popular technique was memorization and repetition. To be specific, some of them tried to acquire new words related to their trading fields (such as prices, colors, etc.) from their relatives or dictionaries, or by memorizing them and using them with foreigners. It was the daily meaning- focused interactions with foreign customers that facilitated the memorization of the new linguistic items. Less common were communication strategies, in which they asked for clarification and feedback from foreigners, which in turn helped them to improve their English speaking skills. Only two people used production strategies, which they prepared in advance the language and used them when applicable.

\subsection{English speaking skill competence of small traders in Hanoi's Old Quarter}

\section{- Linguistic competence}

Table 3. Linguistic competence of small traders, assessed by foreigners

\begin{tabular}{|c|c|c|c|c|c|c|}
\hline No & $\begin{array}{l}\text { Linguistic competence } \\
\text { indicators }\end{array}$ & $\begin{array}{l}\text { None of the } \\
\text { occasions }\end{array}$ & $\begin{array}{l}\text { Some of the } \\
\text { occasions }\end{array}$ & $\begin{array}{c}\text { Half of the } \\
\text { occasions }\end{array}$ & $\begin{array}{l}\text { Most of } \\
\text { the } \\
\text { occasions }\end{array}$ & $\begin{array}{l}\text { All of the } \\
\text { occasions }\end{array}$ \\
\hline 1 & $\begin{array}{l}\text { The small traders } \\
\text { accurately understood the } \\
\text { meaning of your words. }\end{array}$ & $1 \%$ & $40 \%$ & $26 \%$ & $27 \%$ & $6 \%$ \\
\hline 2 & $\begin{array}{l}\text { The small traders were } \\
\text { able to use vocabulary } \\
\text { with correct meanings. }\end{array}$ & $2 \%$ & $46 \%$ & $22 \%$ & $23 \%$ & $7 \%$ \\
\hline 3 & $\begin{array}{l}\text { The vocabulary that the } \\
\text { small traders used was } \\
\text { accurate in forms. }\end{array}$ & $22 \%$ & $42 \%$ & $15 \%$ & $18 \%$ & $3 \%$ \\
\hline 4 & $\begin{array}{l}\text { The small traders } \\
\text { pronounced the words } \\
\text { correctly. }\end{array}$ & $19 \%$ & $38 \%$ & $21 \%$ & $20 \%$ & $2 \%$ \\
\hline 5 & $\begin{array}{l}\text { The small traders showed } \\
\text { accurate word stress. }\end{array}$ & $12 \%$ & $36 \%$ & $22 \%$ & $27 \%$ & $3 \%$ \\
\hline 6 & $\begin{array}{l}\text { The small traders had } \\
\text { monotonous tone when } \\
\text { they spoke. }\end{array}$ & $16 \%$ & $25 \%$ & $32 \%$ & $21 \%$ & $6 \%$ \\
\hline 7 & $\begin{array}{l}\text { The speech of the small } \\
\text { traders was grammatically } \\
\text { correct. }\end{array}$ & $10 \%$ & $48 \%$ & $22 \%$ & $17 \%$ & $3 \%$ \\
\hline
\end{tabular}

Table 3 suggests that most small traders in Hanoi's Old Quarter possessed limited linguistic competence. Nearly half of the foreigners reported that the majority of small traders knew only a few English words related to prices, colors, and sizes of their own merchandise. However, when the conversations were extended to cover a wider range of topics such as materials, function and utility of the products, they often failed to provide proper answers. The following exchange observed by the researchers is a typical case in point:

Customer: What is this made of?

A small trader: Fourteen

Customer: I mean what is it made of, the material?

A small trader: Sapa 
This conversation between a middle-aged trader and a tourist illustrated the trader's inadequacy of lexical items. She only knew some basic vocabulary about the price, and the origin of the product and applied them to all situations, irrespective of appropriateness. Hence it came as little surprise that even more communication breakdowns occured when the topics were extended beyond their familiar business exchanges. For instance, a Canadian tourist commented that the small traders did not "have the necessary vocabulary to give directions to tourists". Sharing the same opinion, a Spanish tourist said she asked a trader "how to go from here to there, what we are going to see near the hostel, where we eat breakfast when we are hungry". However, the instructions she received was hard to comprehend: "She writes me the address of three places for breakfast, but we don't even know the streets, $[\ldots]$ so we were like: what is this place or this place. I don't even know where am I!". As can be seen from these situations, the lack of vocabulary in particular and linguistic competence in general of the locals left many tourists unaided and confused when travelling around in Hanoi. This is a limitation to be addressed to enhance the quality of international tourism in Hanoi as well as in Vietnam.

In terms of pronunciation, a staggering $57 \%$ of foreigners argued that very few traders in
Hanoi's Old Quarter pronounced English words correctly. For example, final consonant sounds were frequently omitted: "price" is pronounced /prai/ instead of /prais/. Some traders equated the pronunciation of English vowels and consonants with that of Vietnamese, saying "đô la" instead /'dblor /, /s/ instead of / $/$ and / $\mathrm{z} /$ instead of $/ \theta /$. Despite many mistakes in pronunciation, most traders' pronunciation was comprehensible enough for these foreigners. In terms of word stress and intonation, most small traders spoke monotonously. Only few managed to vary their tones to express emotions as suggested by the foreign participants.

\section{- Discourse competence}

Since most small traders only uttered language chunks (i.e., separate words or phrases such as "very cheap", "ten thousand") instead of complete sentences (Table 4), foreign tourists usually had to string separated linguistic items to form a complete message. Few people managed to say a full sentence like Lan (e.g. "No, you put perfume inside"). As can be seen though observations and interviews alike, many small traders responded promtly about familiar topics and functions such as asking about price or color. Yet, when asked to perform other functions and discuss other topics, they were often confused, answered hesitantly, or remained silent.

Table 4. Discourse competence of small traders

\begin{tabular}{|c|c|c|c|c|c|c|}
\hline No & $\begin{array}{l}\text { Discourse } \\
\text { competence } \\
\text { indicators }\end{array}$ & $\begin{array}{l}\text { None of } \\
\text { the } \\
\text { occasions }\end{array}$ & $\begin{array}{c}\text { A few } \\
\text { occasions }\end{array}$ & $\begin{array}{l}\text { Half of the } \\
\text { occasions }\end{array}$ & $\begin{array}{l}\text { Most of the } \\
\text { occasions }\end{array}$ & $\begin{array}{l}\text { All of the } \\
\text { occasions }\end{array}$ \\
\hline 1 & $\begin{array}{l}\text { The small traders } \\
\text { spoke in separate } \\
\text { words instead of } \\
\text { complete sentences. }\end{array}$ & $2 \%$ & $23 \%$ & $28 \%$ & $37 \%$ & $10 \%$ \\
\hline 2 & $\begin{array}{l}\text { The small traders } \\
\text { had little pause/ } \\
\text { hesitation. }\end{array}$ & $4 \%$ & $23 \%$ & $39 \%$ & $19 \%$ & $15 \%$ \\
\hline
\end{tabular}

\section{- Sociolinguistic competence}

Figure 3 depicts that the majority of small traders demonstrated polite attitude and responses. They were often friendly, helpful and hospitable with polite greetings and smiles at visitors. Only in some cases, traders had pushy manners or expressed anger when the customers refused to purchase the products. 
Sometimes, it could also be attributed to the limited lingustic competence of the traders. As reported by the foreign tourists, they prefer to have more conversations with the small traders other than just negotiating the price. One respondent said: "In my country, people say hi, hello, how are you, where are you from, .... and then you go to the point, go to the price", but here people showed the price: "yes, no and that's it". Therefore, it is crucial to instruct small traders on how to communicate with foreigners to be polite and avoid possible cultural conflicts. For example, they should not ask the foreigners about age, or marital status, which might be acceptable in Vietnam, but considered too personal and impolite in many cultures.

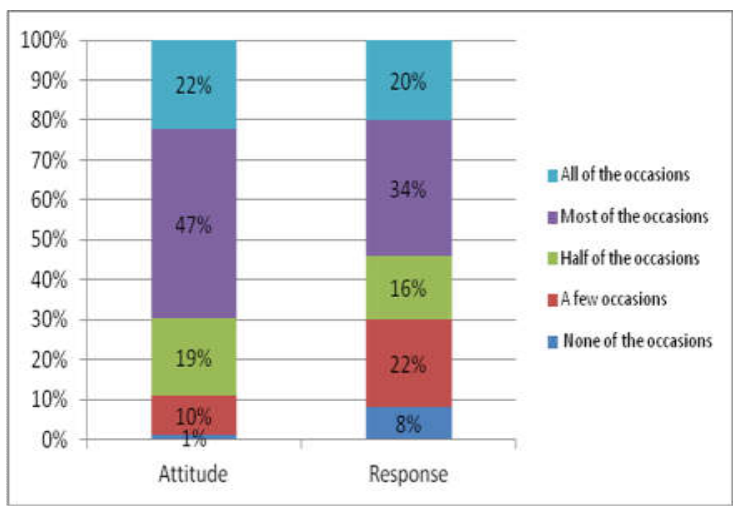

Figure 3. Sociolinguistic competence of small traders.

\section{- Strategic competence}

As indicated in Figure 4, only a handful of small traders were able to recognize and correct their mistakes. The majority of them used nonverbal language to compensate for language deficiency (i.e. hand gestures to refer to objects, calculate for prices, pictures for product demonstration, etc.). To recapitulate, the English speaking skills of the majority of small traders in Hanoi's Old Quarter were insufficient in terms of grammatical, discourse, and sociolinguistic competence. However, with strategic compehence, the language barrier between the small traders and foreign visitors was partly removed.

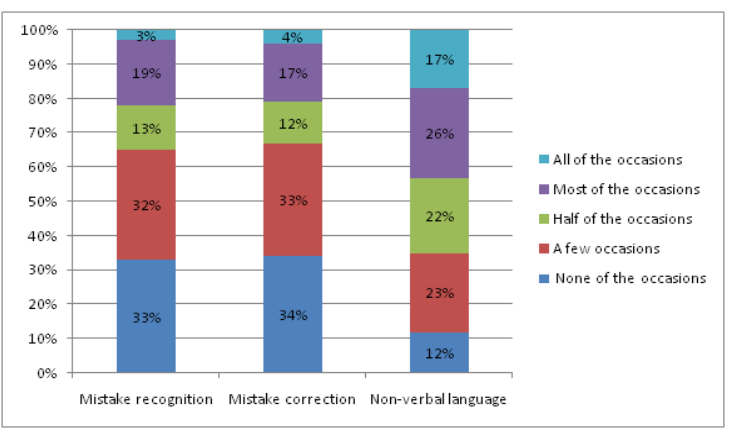

Figure 4. Strategic competence of small traders.

\section{Conclusion and suggestions}

To sum up, the study suggests that small traders in Hanoi's Old Quarter relies on a number of sources, rather than natural settings only, to acquire their English speaking skills. In their acquisition, these traders employed various tecnhiques such as memorization and repetition, production and communication strategies to process the language input from various sources for their spoken output. As for their speaking competence, small traders were claimed by their foreign customers to have limited grammatical, sociolinguistic and discourse competence. Yet, these inadequacies were at times made up for by their decent strategic competence, especially the use of body language.

From these conclusions, we suggest that any attempt to foster and enhance the English speaking skills of small traders in Hanoi's Old Quarter should consider the followings: First, the primary goal should be the ability to conduct authentic communication with foreign customers in their own settings. Second, since a limited repertoire of survival, chunky English proved extremely limited, these small traders should be provided with not only sufficient language related to their trading activities (souvenirs, paintings, handmade items, clothes, etc.) but also to carry out other context-related functions, such as assisting these foreigners in daily communications (e.g. showing the way) and expanding the conversations (e.g. discussing Vietnamese culture, handicrafts and 
businesses). Moreover, cultural knowledge about Vietnam as well as some nations around the world should also be included in the instruction to avoid cultural clashes and foster mutual understanding. In addition, authentic, functional and communicative learning might be of utmost relevance to these traders, as opposed to traditional grammar-based or rote learning which failed to serve their daily needs. Finally, there are practical concerns as well. The instruction, in whatever form it may take, should allow for the busy life of small traders. As far as it is concerned, experiential, participatory and blended learning could be more relevant for these traders, as learning and teaching could enjoy and benefit from better authenticity, mobility and autonomy.

\section{References}

[1] Vietnam National Administration of Tourism, International visitors to Vietnam in July and 7 months of 2016, Availble from http://vietnamtourism.gov.vn/english/index.php/ cat $/ 1501$

[2] Nguoi Lao Dong Online Newspaper, Học ngoại ngữ ở... chợ [Learning foreign languages at ... the market], Available from http://nld.com.vn/dia-phuong/hoc-ngoai-ngu-ocho-20120303050743725.htm, 2012.

[3] Phu Nu Thu Do Online Newspaper, Tiểu thương Hà Nội cần học Tiếng Anh. [Small traders in Hanoi need to learn English], Available from http://baophunuthudo.vn/sites/ePaper/PNTD/Det ail.aspx?ArtId=15953, 2013.
[4] Thanh Nien Online Newspaper, Học ngoại ngữ để làm du lịch. [Learn English for tourism purposes], Available from http://thanhnien.vn/doi-song/nhip-song-diaphuong/hoc-ngoai-ngu-de-lam-du-lich17708.html, 2013.

[5] Florez, M. C., Center for adult English language acquisition. Retrieved from http://www.cal.org/caela/esl_resources/digests/S peak.html, 1999.

[6] Bygate, M., Speaking, Oxford University Press, 1987.

[7] Sakale, S., Rethinking Speaking Skills in EFL (English as a Foreign Language) Settings. SinoUS English Teaching, Available from http://www.davidpublishing.com/davidpublishin g/upfile/6/3/2012/2012060383316321.pdf, 2012.

[8] Ellis, R., Input, interaction and second language acquisition. In Understanding second language acquisition (7th ed., pp. 127-163). Oxford University Press, 1991.

[9] Nunan, D., From the Traditional to the Contemporary in Second Language Teaching and Learning. In Second language teaching and learning (pp. 69-91). Heinle \& Heinle, 1999.

[10] Krashen, S. D., Principles and practice in second language acquisition (1st ed.). Oxford: Pergamon, 1982.

[11] Littlewood, W., Communicative Language Teaching - An introduction. Great Britain: Cambridge University Press, 1981.

[12] Richards, J. C., Communicative Language Teaching Today. Singapore: SEAMEO Regional Language Center, 2005.

[13] Richards, J. C., \&Schmidt, R. W. (Eds.)., Language and Communication. London: Longman, 1983. 